J. Clin. Chem. Clin. Biochem.

Vol. 18, 1980, pp. 215-220

\title{
Radioimmunoassay Evaluation and Quality Control by Use of a Simple Computer Program for a Low Cost Desk Top Calculator
}

\author{
By S. Schwarz \\ Institute of General and Experimental Pathology, University of Innsbruck, Austria
}

(Received March 30/September 28, 1979)

\begin{abstract}
Summary: A simple computer program for the data processing and quality control of radioimmunoassays is presented. It is written for low cost programmable desk top calculator (Helwett Packard 97), which can be afforded by smaller laboratories. The untreated counts from the scintillation spectrometer are entered manually; the printout gives the following results: initial data, logit-log transformed calibration points, parameters of goodness of fit and of the position of the standard curve, control and unknown samples dose estimates (mean value from single dose interpolations and scatter of replicates) together with the automatic calculation of within assay variance and, by use of magnetic cards holding the control parameters of all previous assays, between assay variance.
\end{abstract}

\section{Auswertung und Qualitätskontrolle von Radioimmunoassays mit einem einfachen Programm für einen kostengünstigen Tischrechner}

Zusammenfassung: Es wird hier ein Programm für einen allgemein erschwinglichen Kleinrechner (Hewlett Packard 97) vorgestellt, welches eine vollständige Datenverarbeitung von Radioimmunoassays erlaubt. Die Eingabe der Roh-Zählraten - direkt vom Ausdruck des Szintillationsspektrometers - erfolgt manuell, ebenso die der Standardkonzentrationen. Die Berechnungen werden anhand des über Magnetkarte eingelesenen Programms automatisch durchgeführt. Die Roh-Zählraten werden um die unspezifische Bindung korrigiert und für jede beliebige Anzahl von Wiederholungsbestimmungen wird der Mittelwert berechnet. Standards werden nach der logit-log Methode transformiert und als solche ausgedruckt, um anhand einer handgezeichneten Kurve die Sinnfälligkeit der späteren Berechnungen abschätzen zu können. Durch lineare Regression nach der Methode der kleinsten Fehlerquadrate wird der Korrelationskoeffizient, die Steigung, der y-Achsenschnittpunkt, die x-Achsenschnittpunkte bei effektiver Dosis (ED) 85, 50 und 15 ermittelt und ausgedruckt. Die unbekännten Konzentrationen werden nach logit-Transformation an der gespeicherten Kurve interpoliert. Ausgedruckt werden Mittelwert und Standardfehler, welche aus den Dosiseinzelwerten berechnet werden. Am Ende der Auswertung gibt der Rechner in zusammengefaßter Form insgesamt 12 Kenngrößen der aktuellen Testgüte aus: Total-Zählrate, \% unspezifịsche und \% Anfangsbindung, Steigung, Korrelationskoeffizient, mittlere Restvarianz, Testempfindlichkeit (ED 85), Dosịs der Halbsättigung (ED 50), ED 15, gefundene Werte der niedrigen und hohen Kontrollprobe, intra-assay Varianż. Von allen früheren Testen sind insgesamt 8 Kontrollgrößen auf Magnetkarte gespeichert. Diese werden nach Einlesen in den Rechner um das jeweilige Tagesergebnis erweitert, als kumulative Mittelwerte ausgedruckt und auf die Magnetkarte zurückgespeichert. Als letzter Wert dieser automatisierten Qualitätskontrolle erscheint die inter-assay Varianz.

\section{Introduction}

A number of highly sophisticated and intelligent computer programs for radioimmunoassay data reduction have been developed (e.g. 1-5). They all have one drawback, however, in that they require expensive hardware. Such hardware is possessed by only a minority of laboratories, so that the application of these programs is limited.
This paper does not contribute a further model, but presents a very simple, ready-to-use computer program for a cheap Hewlett Packard (HP 97) calculator. Thus, in addition to saving time, many laboratories still restricted to graphical methods are thus enabled to approach a more comprehensive radioimmunoassay data reduction, assay evaluation and statistical quality control without additional workload and cost (this calculator costs approximately 1000 US dollars). 
The underlying algorithm is the logit-log transformation (6) followed by unweighted linear regression analysis which combines clarity of format and data presentation with ease of operation, provided, however, that the principal applicability of this algorithm has first been determined by the assayist. Otherwise, this algorithm (consisting of only 10 steps) may be easily replaced by other models which provide linearization of the standard curve either on a heuristic (such as arcus-sinus or probit) or a mass action law basis (such as the various types of reciprocal bound plots). The major part of this program which provides the organizational structure for statistical treatment of the radioimmunoassay raw data and for the quality control of assays is, however, completely independent of the algorithm employed for transformation of the response and dose variables.

\section{Program Analysis}

The program is written in an operational language, which applies particularly to the HP 97. Since in most cases only the bound fraction (B) is counted, the program has been designed primarily for that situation. Without additional options (such as free fraction counting or correction subroutines) it comprises 662 steps.

Figure 1 shows the flow chart of the whole program.

\section{Mathematics}

The following abbreviations are used:

B: bound radioactivity (untreated counts/min direct from counter);

NSB: non specifically bound radioactivity;

$\mathrm{B}_{0}$ : initially bound radioactivity (zero standard);

T: total radioactivity added;

ED: effective dose;

$\mathrm{i}$ suffix for the $\mathrm{i}^{\text {th }}$ standard;

u: $\quad$ suffix for unknown sample;

$\mathrm{L}_{\mathrm{i}-\mathrm{k}}$ : known concentration of cold ligand;

$\mathbf{L}_{\mathbf{i}-c}$ : computed concentration of cold ligand;

$\mathrm{m}$ : slope of the standard curve;

b: $\quad y$-intercept;

$r$ : coefficient of correlation;

RSV: residual variance;

AF: aliquot factor (conversion of units per assay tube into diagnostically appropriate final units);

SEM\%: standard error of the mean in percent of the mean;

$L^{*}$ : labelled ligand.

$$
\begin{aligned}
\operatorname{logit} \mathrm{B} / \mathrm{B}_{0} & =\operatorname{logit} \frac{\mathrm{B}^{\prime}-\mathrm{NSB}}{\mathrm{B}_{0}^{\prime}-\mathrm{NSB}}=\ln \frac{\mathrm{B} / \mathrm{B}_{0}}{1-\mathrm{B} / \mathrm{B}_{0}} \\
& =\ln \frac{\mathrm{B}^{\prime}-\mathrm{NSB}}{\mathrm{B}_{0}^{\prime}-\dot{\mathrm{B}}^{\prime}}
\end{aligned}
$$

where $B^{\prime}$ and $B_{0}^{\prime}$ are untreated radioactivity counts bound, and $B$ and $B_{0}$ are corrected for $\overline{\mathrm{NSB}}$ radioactivity counts

when $\mathrm{ED} 85 / 50 / 15=10^{\mathrm{x}}(\mathrm{x}=$ dose $)$,

$$
\mathrm{x}_{\mathrm{ED} 85}=\frac{\ln \left\{\frac{\left[\left(\mathrm{B}_{0}^{\prime}-\mathrm{NSB}\right) \cdot 0.85+\mathrm{NSB}\right]}{\mathrm{B}_{0}^{\prime}-\left[\left(\mathrm{B}_{0}^{\prime}-\mathrm{NSB}\right) \cdot 0.85+\mathrm{NSB}\right]}\right\}-\mathrm{b}}{\mathrm{m}}
$$

The corresponding variables $\left(\log \mathrm{L}_{\mathrm{i}-\mathrm{k}}\right.$ and $\operatorname{logit} \mathrm{B}_{\mathrm{i}} / \mathrm{B}_{0}$ as $\mathrm{X}$ and $\mathrm{Y}$, respectively) are stored as $\Sigma \mathrm{X}, \Sigma \mathrm{X}^{2}, \Sigma \mathrm{Y}, \Sigma \mathrm{Y}^{2}$, $\Sigma \mathrm{XY}$ and $\mathrm{N}$ (number of pairs = calibration points).

The dose-response relationship according to the logitlog model is given by the equation

$$
\operatorname{logit} \mathrm{B} / \mathrm{B}_{0}=-2.303 \cdot \log \mathrm{L}+2.303 \cdot \log \mathrm{L}^{*}
$$

which corresponds to the general form of the equation for a straight line $(y=m \cdot x+b)$. For computation of the parameters $r, m$ and $b$, the general rules of linear regression statistics are applied (7.).

$$
\begin{aligned}
& \operatorname{RSV}_{\mathbf{i}}=\left(\frac{\mathrm{L}_{\mathrm{i}-\mathrm{k}}-\mathrm{L}_{\mathrm{i}-\mathrm{c}}}{\mathrm{L}_{\mathrm{i}-\mathrm{k}}}\right)^{2} ; \\
& \overline{\mathrm{RSV}}=\frac{\sum_{\mathrm{i}=1}^{\mathrm{n}} \mathrm{RSV}_{\mathrm{i}}}{\mathrm{n}} .
\end{aligned}
$$

when $L_{u}=10^{x}$,

$$
\mathrm{x}_{\mathrm{u}}=\frac{\operatorname{logit} \mathrm{B}_{\mathrm{u}} / \mathrm{B}_{0}-\mathrm{b}}{\mathrm{m}}
$$

Mean concentration values and variance (SEM\%) for replicate unknowns are calculated from single dose interpolations, thus taking into account both the steepness of the standard curve and the position of the sample "upon" it.

$$
\text { mean final concentration }=x_{u} \cdot A \bar{F}
$$

Experimental precision index $(\mathrm{EPI})=$ mean value of SEM\%s of all "patients" determined in replicates in the assay.

Between assay variance (\%)

$$
=\frac{(\mathrm{SD} / \overline{\mathrm{x}})_{\text {low c. }}+(\mathrm{SD} / \overline{\mathrm{x}})_{\text {high } \mathrm{c} .}}{2} \cdot 100
$$

where $\bar{x}$ is the averaged control samples' dose estimate in all previous assays including the last one $(\mathrm{SD}=$ standard deviation, $\mathrm{c} .=$ control sample).

Figures 2 and 3 show a typical radioimmunoassay protocol with the printout as generated by this program. $A$ step by step description for the operation of the program, together with a complete program listing with some additional options, can be obtained from the author upon request.

\section{Discussion}

The ever increasing impact of radioimmunoassay in the field of medical diagnostics necessitates the intrôduction of computers (compare 1.c. (8)). Special attention is now focussed on quality control and standardization to achieve worldwide comparability of radioimmunoassay results, a goal difficult to approach for the many laboratories still restricted to graphical mêthods. For these 


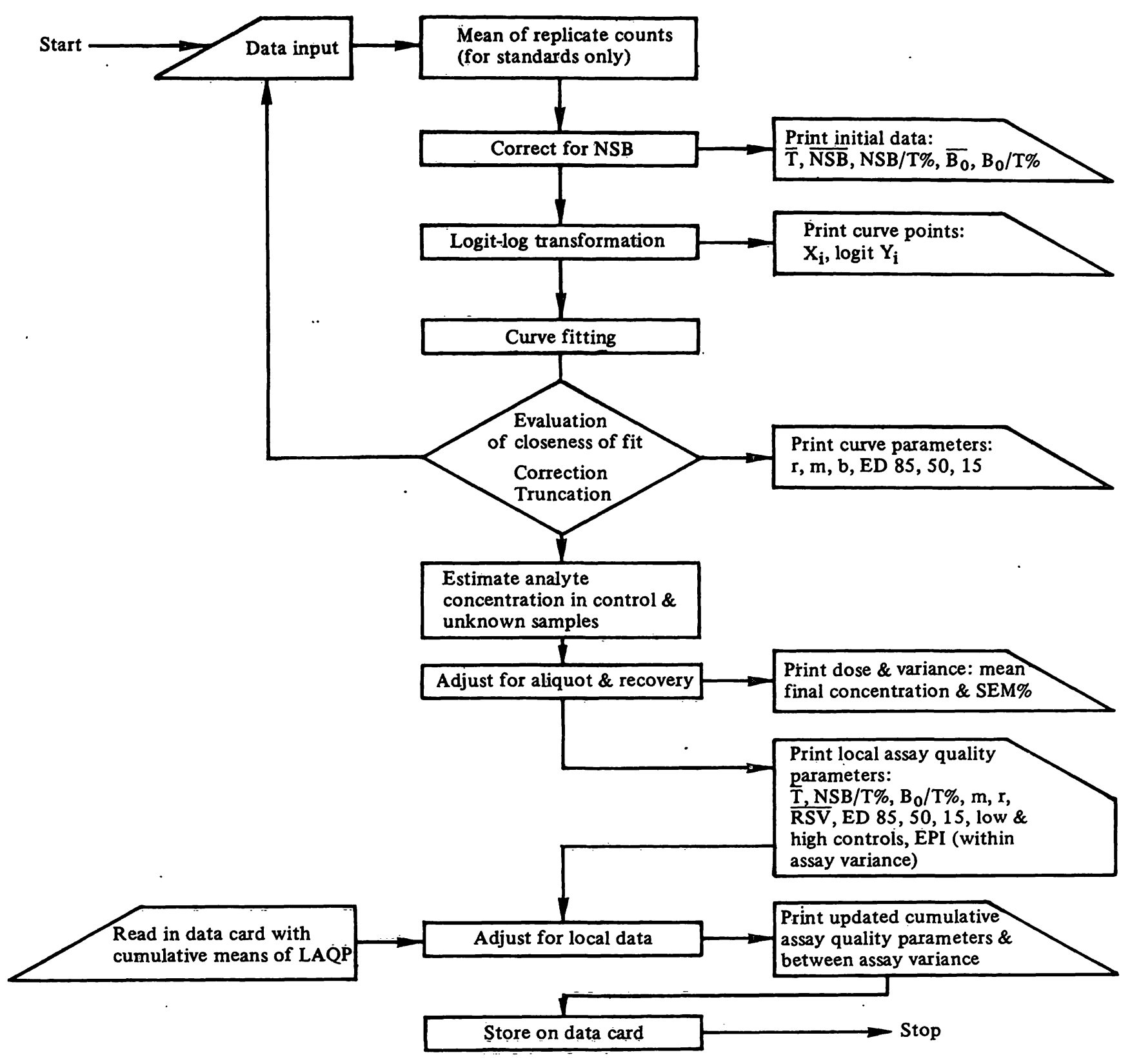

Fig. 1. Flow chart of the whole program for radioimmuñoassay analysis and quality control ("LAQP": local assay quality control parameters).

laboratories we have attempted to develop a simple computer program which provides the organizational software structure for complete radioimmunoassay data reduction, including statistical treatment of the raw data and quality control of the final standard curve parameters and control samples dose values. As presented recently (9), this program has the advantage of being immediately processable on a low cost desk top calculator.

The wide application of the logit-log algorithm and its advantages (derived from the mass action law; simplicity; "robustness"; standardized format; comparability of assay parameters by dimensionless numerical values independent of the total radioactivity added per assay tube; its practicability for assay documentation and thus quality control and assay optimization) led us to choose this model as an example for incorporation into our program. Since, however, it is just a small and distinct program module (subroutine of 10 steps), it may be easily replaced by a variety of other algorithms which linearize the radioimmunoassay standard curve, the choice being dependent on the type of assay and the operator's personal experience and preference.

Heteroscedasticity makes necessary the implementation of appropriate weighting functions before the linear regression analysis. But weighting on the basis of scatter of replicates may involve a considerable sampling error: triplicates are commonly the upper limit of practicability in radioimmunoassay performance. A 


\begin{tabular}{|c|c|c|}
\hline Tube & Dose: ng/tube & $\begin{array}{l}\text { Counts/min } \\
\text { bound }\end{array}$ \\
\hline
\end{tabular}

\begin{tabular}{|c|c|c|}
\hline 0 & Total radioactivity added & 6905 \\
\hline $\begin{array}{l}1 \\
2 \\
\end{array}$ & Non specific binding & $\begin{array}{l}521 \\
500 \\
\end{array}$ \\
\hline $\begin{array}{r}3 \\
4 \\
\end{array}$ & Zero standard & $\begin{array}{l}3816 \\
3900 \\
\end{array}$ \\
\hline $\begin{array}{l}5 \\
6 \\
\end{array}$ & St. $1 \quad 0.0078$ & $\begin{array}{l}3422 \\
3387 \\
\end{array}$ \\
\hline $\begin{array}{l}7 \\
8 \\
\end{array}$ & St. 20.0156 & $\begin{array}{r}3019 \\
3034 \\
\end{array}$ \\
\hline $\begin{array}{r}9 \\
10 \\
\end{array}$ & St. $3 \quad 0.0312$ & $\begin{array}{l}2641 \\
2413 \\
\end{array}$ \\
\hline $\begin{array}{l}11 \\
12 \\
\end{array}$ & St. $4 \quad 0.0625$ & $\begin{array}{r}2038 \\
2053 \\
\end{array}$ \\
\hline $\begin{array}{l}13 \\
14 \\
\end{array}$ & St. $5 \quad 0.125$ & $\begin{array}{l}1503 \\
1473 \\
\end{array}$ \\
\hline $\begin{array}{l}15 \\
16 \\
\end{array}$ & St. $6 \quad 0.25$ & $\begin{array}{l}1027 \\
1061 \\
\end{array}$ \\
\hline
\end{tabular}

\begin{tabular}{|c|c|}
\hline $\mathrm{T}$ & $6905 . * * *$ \\
\hline $\begin{array}{l}\text { NSB } \\
\text { NSB/T\% }\end{array}$ & $\begin{array}{r}511 . * * * \\
7.4 * * *\end{array}$ \\
\hline $\begin{array}{l}\mathrm{B}_{0} \\
\mathrm{~B}_{0} / \mathrm{T} \%\end{array}$ & $\begin{array}{r}3858 . * * * \\
48.5 * * *\end{array}$ \\
\hline \multirow[t]{5}{*}{$\begin{array}{l}L_{1-k} \\
\text { logit }_{1}\end{array}$} & $\begin{array}{r}0.0078 * * * \\
1.85 * * * *\end{array}$ \\
\hline & $\begin{array}{r}0.0156 * * * \\
1.11 * * *\end{array}$ \\
\hline & $\begin{array}{r}0.0313 * * * \\
0.42 * * *\end{array}$ \\
\hline & $\begin{array}{r}0.0625 * * * \\
-0.17 * * *\end{array}$ \\
\hline & $\begin{array}{r}0.1250 * * * \\
-0.89 * * * *\end{array}$ \\
\hline $\begin{array}{l}\mathrm{L}_{6-\mathrm{k}} \\
\operatorname{logit}_{6}\end{array}$ & $\begin{array}{r}0.2500 * * * \\
-1.66 * * *\end{array}$ \\
\hline $\mathbf{r}$ & $-0.99929 * * *$ \\
\hline $\begin{array}{l}\mathrm{m} \\
\mathrm{b}\end{array}$ & $\begin{array}{l}-2.29134 * * * \\
-2.99371 * * *\end{array}$ \\
\hline $\begin{array}{l}\text { ED } 85 \\
\text { ED } 50 \\
\text { ED } 15\end{array}$ & $\begin{array}{l}0.0086 * * * \\
0.0494 * * * \\
0.2822 * * *\end{array}$ \\
\hline $\begin{array}{l}\text { ED S1 } \\
\text { ED S2 } \\
\text { ED S3 } \\
\text { ED S4 } \\
\text { ED S5 } \\
\text { ED S6 }\end{array}$ & $\begin{array}{l}0.0077 * * * \\
0.0162 * * * \\
0.0325 * * * \\
0.0583 * * * \\
0.1202 * * * \\
0.2625 * * *\end{array}$ \\
\hline$\overline{\mathrm{RSV}}$ & $0.001982 * * *$ \\
\hline \multirow[t]{3}{*}{ AF 5000} & $5000.000000 * * *$ \\
\hline & $\begin{array}{r}96.3 * * * \\
13 . * * *\end{array}$ \\
\hline & $\begin{array}{r}744.7 * * * \\
6 . * * *\end{array}$ \\
\hline EPI & 9.6 \\
\hline
\end{tabular}

Fig. 2. Typical radioimmunoassay protocol sheet (for estradiol-17 $\beta$, corresponding to assay no. 2 in fig. 3 ).

Raw-counts bound under "counts/min bound", originally transcribed from the counter printout; on the right hand side, a continuous outprint as performed by the Hewlett Packard 97 calculator.

response-error relationship from several pooled assays is, on the other hand, not necessarily applicable to subsequent assays. Thus, mathematical weighting, including iterative processing may also create problems, in addition to the requirement of larger computer capacities.
Extensive theoretical sampling experiments have revealed (10) that weighted regression analysis yields results significantly different and better from unweighted analysis only when more than 10 replicates are used. Furthermore it was shown (11) that for any radioimmunoassay giving a straight line Scatchard'plot 


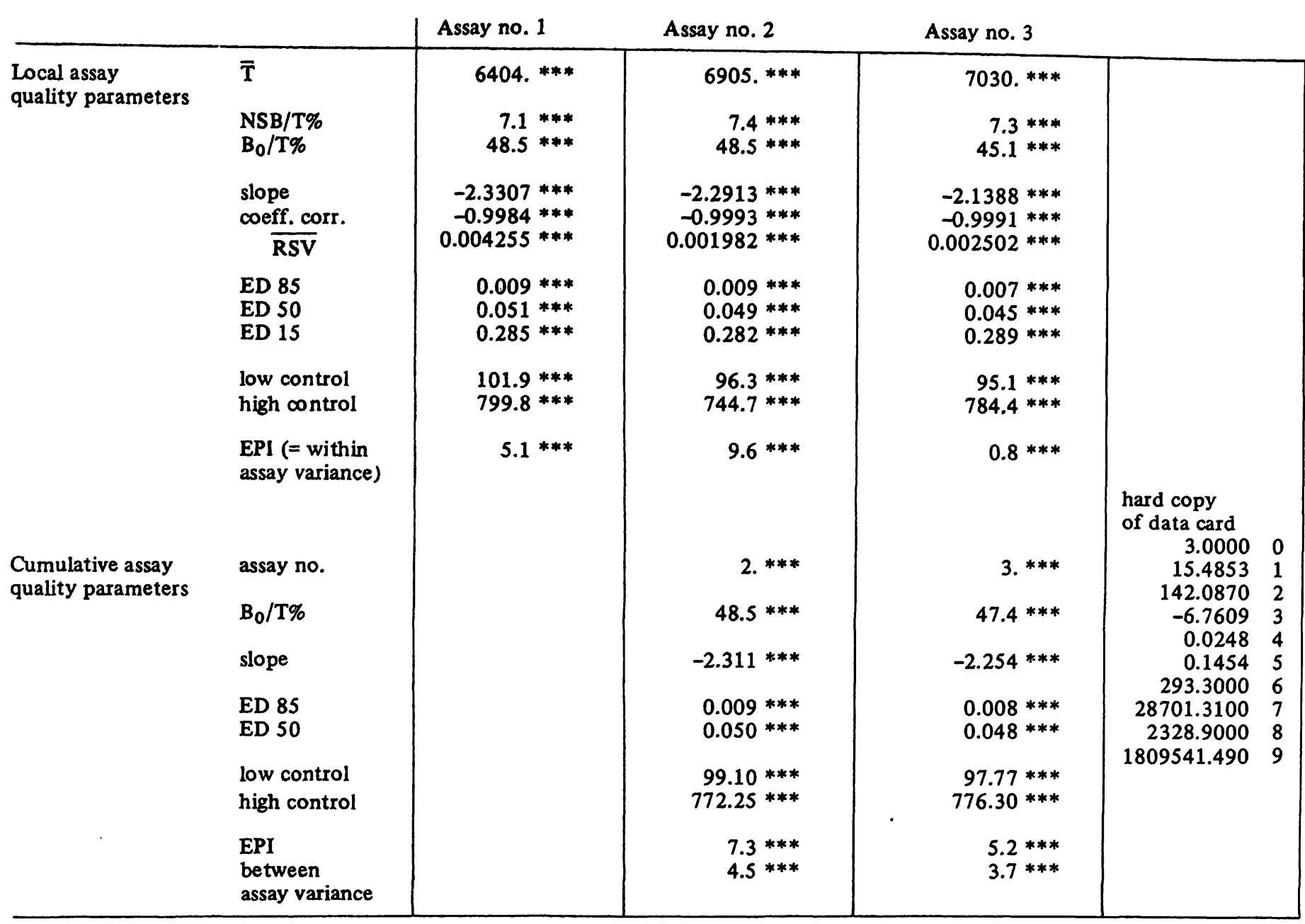

Fig. 3. Radioimmunoassay quality control record sheet. Printouts are done by the quality control part of this program. Assay No. 2 is identical with that shown in detail in fig. 2. The hard copy of the magnetic data card is kept only until the next assay.

Tab. 1. Comparison of residual variances yielded in 3 different radioimmunoassay algorithms. Raw data (cpm-B and $L_{i-k}$ ) in column 1 were taken from tab. 4 (renin standard curve) in the paper of Naus (17).

Model (A): B/F vs. L, as proposed by Naus;

Model (C): 1/cpm-B vs. L (reciprocal bound plot);

(B) and (C) (unweighted logit-log) are calculated by unweighted linear regression analysis. In column 2, the transformed metameters of cpm-B are listed, in column 3 the calculated standard concentrations $\left(L_{i-c}\right)$ from the respective models. In column 4, the residual variances $\left(\mathrm{RSV}_{\mathbf{i}}\right)$ are shown, while the mean $\mathrm{RSV}(\overline{\mathrm{RSV}})$ for each model is given underneath.

\begin{tabular}{|c|c|c|c|c|c|c|c|c|c|c|}
\hline \multirow[t]{2}{*}{ cpm-B } & \multirow[t]{2}{*}{$\begin{array}{l}1 \\
\mathbf{L}_{\mathbf{i}-\mathbf{k}}\end{array}$} & $\overline{\mathbf{B}} / \mathbf{F}$ & $\begin{array}{c}2 \\
\operatorname{logit} B / B_{0}\end{array}$ & $\begin{array}{l}1 / \mathrm{cpm}=\mathrm{B} \\
\times 10^{4}\end{array}$ & \multicolumn{3}{|c|}{$\begin{array}{r}3 \\
L_{i-c}\end{array}$} & \multicolumn{3}{|c|}{$\begin{array}{l}4 \\
\text { RSV } \\
\times 10^{-4} \\
\end{array}$} \\
\hline & & (A) & (B) & (C) & (A) & (B) & (C) & (A) & (B) & (C) \\
\hline \multirow[t]{2}{*}{$\begin{array}{l}8711 \\
6213 \\
4647 \\
3276 \\
2526 \\
2115 \\
1840 \\
1654\end{array}$} & $\begin{array}{r}0 \\
10 \\
25 \\
50 \\
75 \\
100 \\
125 \\
150\end{array}$ & $\begin{array}{l}0.831 \\
0.479 \\
0.319 \\
0.206 \\
0.152 \\
0.124 \\
0.106 \\
0.094\end{array}$ & $\begin{array}{r}\bar{c} \\
0.911 \\
0.134 \\
-0.506 \\
-0.895 \\
-1.137 \\
-1.318 \\
-1.451\end{array}$ & $\begin{array}{l}1.148 \\
1.610 \\
2.152 \\
3.035 \\
3.959 \\
4.728 \\
5.435 \\
6.046 \\
\end{array}$ & $\begin{array}{r}- \\
10.09 \\
24.20 \\
50.25 \\
77.94 \\
102.00 \\
124.35 \\
143.81 \\
\end{array}$ & $\begin{array}{r}- \\
10.09 \\
24.26 \\
49.99 \\
77.60 \\
101.99 \\
125.00 \\
145.32 \\
\end{array}$ & $\begin{array}{r}- \\
6.49 \\
23.38 \\
51.44 \\
79.68 \\
103.65 \\
125.66 \\
144.70 \\
\end{array}$ & $\begin{array}{r}- \\
0.81 \\
10.24 \\
0.24 \\
15.37 \\
4.00 \\
0.27 \\
17.03 \\
\end{array}$ & $\begin{array}{c}- \\
0.81 \\
8.76 \\
0 \\
12.02 \\
3.96 \\
0 \\
9.73 \\
\end{array}$ & $\begin{array}{r}- \\
1232.01 \\
41.99 \\
8.29 \\
38.94 \\
13.32 \\
0.28 \\
12.48 \\
\end{array}$ \\
\hline & & & & & & $\overline{\text { RSV } x}$ & & 6.85 & 5.04 & 192.5 \\
\hline
\end{tabular}


(single class of binding sites), the unweighted linear logit-log algorithm is just as effective as the 4-parameter logistic function (12).

Despite the wide applicability of the logit-log model, there exist a few types of assays, which can not satisfactorily be described in this manner, especially if they do not follow the principles of Ekins" "limited reagents competitive radioimmunoassay" (13). In those cases mass action law-independent algorithms such as "spline smoothing" (14) or the simple graphical methods should be employed. Otherwise in certain circumstances (for example if the calibration point with the lowest or highest concentration significantly deviates from the line, as sometimes happens with the logit-log model), truncation of the standard line may be advocated, so that the working range becomes defined by the points that are compatible with the straight line model. In such a case, unknowns exceeding these limits should be withdrawn from interpolation. We therefore strongly recommend the user of this program to draw a standard curve in logit-log format (as it is printed out) each time before proceeding to the regression analysis (compare fig. 2). Generally, however, when restricting to the limits ED 85 and ED 15 (a kind of "pretruncation"), no further truncation will be necessary: in an ideal logit-log line (slope -2.303 ), 5 doubling increments of standard concentrations ( $=6$ points altogether) cover a 32-fold $\left(=5^{2}\right)$ assay working range, the extremes of which are coincident with the inflexion points of the logit $B / B_{0}$ vs. $B / B_{0}$ relationship. Hyperbolic "blowing up", which artificially exaggerates heteroscedasticity, occurs mainly beyond $\mathrm{B} / \mathrm{B}_{0}=0.85$ and 0.15 , respectively $(15,16)$. And from the data shown in table 1 , one can assume that the unweighted logit-log model is "robust" enough to also effectively linearize assay systems with equilibrium constants unequal for labelled and unlabelled ligand.

A realistic value for between assay variance by use of a computerized quality control approach, will certainly be a reliable guide for assay revision and optimization.

Having performed 10 to 20 assays of a certain type, the mere calculation of "cumulative assay quality control parameters" has to be supplemented by use of control charts of either the SHEWART or the CUSUM (cumulative sums of differences) type.

\section{Acknowledgement}

The author is indebted to Professor Dr. G. Wick for continuous encouragement and support. The reliable technical assistance of Ulrike Debuch, Janis Boyd and Waltraud Stecher is gratefully appreciated.

\section{References}

1. Rodbard, D. \& Lewald, J. E. (1970), Acta Endocrinol. (Kbh.) 64 , Suppl. 147, 79-98.

2. Duddleson, W. G., Midgley, A. R. \& Niswender, G. D. (1972), Comp. Biomed. Res. 5, 205-217.

3. Ekins, R. P. (1974), in Proceed. $2^{\text {nd }}$ Symp. Radioimmunoassay and Related Procedures in Medicine, 91-109, IAEA, Vienna.

4. Vogt, W., Popp, B. \& Knedel, M. (1973), J. Clin. Chem. Clin. Biochem. 11, 438-445.

5. Schöneshofer, M. (1977), Clin. Chim. Acta 64, 1-9.

6. Rodbard, D., Rayford, P. L., Cooper, J. A. \& Ross, G. T. (1968), J. Clin. Endocrinol. Metab. 28, 1412-1428.

7. Spiegel, M. R. (1972), Theory and Problems of Statistics, ch. 13, McGraw Hill Book Co., New York.

8. Challand, G. S. (19.78), Ann. Clin. Biochem. 15, 123-135.

9. Schwarz, S. (1979), J. Steroid Biochem. 11, 1641-1646.
10. Jaquez, J. A. (1973), Biometrics 29, 771-779.

11. Ichihara, K., Yamamoto, T., Kumahara, Y. \& Miyai, K. (1977), Clin. Chim. Acta 79, 331-340 and ibid. 80, 37-47.

12. Rodbard, D. \& Hutt, D. M. (1974), in Proc. $2^{\text {nd }}$ Sympos. Radioimmunoassay and Related Procedures in Medicine, $165=189$, IAEA, Vienna.

13. Ekins, R. P. (1978), in Proceed. $3^{\text {rd }}$ Symp. Radioimmunoassay and Related Procedures in Medicine, 241-268, IAEA, Vienna.

14. Marschner, I., Erhardt, F. \& Scriba, P. C. (1976), in Proceed. $2^{\text {nd }}$ Sympos. Radioimmunoassay and Related Procedures in Medicine, 111-120, IAEA, Viènna.

15. Schwarz, S. (1978), Wiener Klin. Wochenschr. 90, 781-789.

16. Schwarz, S. (1979), Ber. Österr. Ges. Klin. Chem. 2, 6-9.

17. Naus, A. J., Kuppens, P. S. \& Borst, A. (1977), Clin. Chem. $23,1624-1627$.
Dr. Siegfried Schwarz,

Institut für Allgemeine und Experimentelle Pathologie der Universität,

Fritz-Pregl-Straße 3

A-6020 Innsbruck, Österreich 